\title{
Analysis of the water meter management of the urban-rural water supply system
}

\author{
Joanna Gwozdziej-Mazur ${ }^{1,{ }^{*}}$, Kamil Świętochowski ${ }^{1}$ \\ ${ }^{1}$ Department of Technology and Systems of Environmental Engineering, Faculty of Civil and \\ Environmental Engineering, Białystok University of Technology, St. Wiejska 45E, 15-351 Białystok, \\ Poland;
}

\begin{abstract}
Water losses in the water supply network pose a continuous challenge for water companies. Already during designing new networks, the designer assumes that the amount of water demand must be increased by a certain percentage (usually by $10 \%$ of the total average daily water demand for municipal and industrial purposes) due to the possible occurrence of water losses. Water loss is meant the difference between the amount of water injected into the network and the amount of water used and invoiced, i.e. that brings income for the water supply company. Proper water metering management helps to limit water losses. This paper presents analysis of the water meter management of urban-rural water supply system.
\end{abstract}

\section{Introduction}

Water leaks are an important part of the water balance in a water company. For every company, it is important for the level of revenue water to be as close to $100 \%$ as possible. Meanwhile, there should be as little Non-Revenue Water as possible. Much attention is paid in the literature to the issue of limiting real water losses[1-5]. However, the level of NonRevenue Water is not only affected by Real Losses but also by Apparent Losses and Unbilled Authorized Consumption. Apparent Losses consist of such elements as: Consumption Metering Errors, Unauthorized Consumption, Systematic Data Handling Errors. Unbilled Authorized Consumption consists of the following elements: Unbilled Metered Authorized Consumption and Unbilled Unmetered Authorized Consumption [6,7]. As metering of consumers' water consumption was introduced in Poland, the amount of water consumed per household decreased. [8,9]. The amount of consumption decreased nearly two-fold in cities, from 250 to approx. $100 \mathrm{l} /$ person/day. This is linked to many operational problems of water supply networks, i.e. excessive diameters, low water flow rate, etc.. The same problem appeared during measurement of the amount of water consumed. Water meters installed for consumers are usually too large. In addition, there are also problems related to attempts to cheat water meter readings and measurement accuracy class [10]. Proper water meter management has an influence on the quality of measuring water consumption.

\footnotetext{
* Corresponding author: j.mazur@pb.edu.pl
} 


\section{Materials and methods}

\subsection{Descriptions of the water supply system}

Studies were conducted in an urban-rural water supply system situated in northern Poland. The scope of the study covered the years 2010-2016. The length of distribution pipes and mains of the analyzed water supply network changed from $131 \mathrm{~km}$ in 2010 to $185 \mathrm{~km}$ in 2016. Meanwhile, the percentage share of the network in the rural area relative to the entire network increased from $52.6 \%$ to $65.9 \%$. The length of the network in the rural area increased nearly two-fold. Within the analyzed period, the number of consumers connected to the water supply network in the rural area increased by nearly $50 \%$. It was possible to conduct studies of water meter management and water sales structure in the urban-rural water supply network on the basis of materials obtained from the water company.

\subsection{Selection of the diameter of the water meter}

Estimated optimization of diameters and costs was performed on the basis of guidelines for water supply network designers "Water meter selection procedure" from MPWiK in Włocławek (table 1) and "Guidelines for designing and construction of water supply and wastewater networks and service lines" PWiK of the Częstochowski District (table 2). It was noted that the authors of the "Guidelines for designing and construction of water supply and wastewater networks and service lines" PWiK of the Częstochowski District assumed safety coefficients from 1.1 to 1.25 for water meters DN20 and DN40 in the selection of water meters based on predicted water consumption for 5 years of water meter operation. The details are presented in table 2.

Table 1. Water meter selection according to "Water meter selection procedure" [11].

\begin{tabular}{|c|c|c|}
\hline $\begin{array}{c}\text { Daily water } \\
\text { consumption in } \\
\text { object } \mathrm{m}^{3}\end{array}$ & $\begin{array}{c}\text { Number of premises in } \\
\text { building of single-family } \\
\text { houses }\end{array}$ & $\begin{array}{c}\text { Water meter size DN for } \\
\text { typical Qn parameters }\end{array}$ \\
\hline $0.00-1.00$ & $<4$ & $15\left(1.5 \mathrm{~m}^{3} / \mathrm{h}\right)$ \\
\hline $1.01-5.90$ & $4-20$ & $20\left(2.5 \mathrm{~m}^{3} / \mathrm{h}\right)$ \\
\hline $6.00-15.00$ & $21-45$ & $25\left(3.5 \mathrm{~m}^{3} / \mathrm{h}\right)$ \\
\hline $15.01-25.00$ & $46-75$ & $32\left(6.0 \mathrm{~m}^{3} / \mathrm{h}\right)$ \\
\hline $25.01-50.00$ & $76-125$ & $40\left(10.0 \mathrm{~m}^{3} / \mathrm{h}\right)$ \\
\hline $51.00-90.00$ & Pressure boosting plant & $50\left(15.0 \mathrm{~m}^{3} / \mathrm{h}\right)$ \\
\hline $90.00-200.00$ & Pressure boosting plant & $80\left(30.0 \mathrm{~m}^{3} / \mathrm{h}\right)$ \\
\hline
\end{tabular}


Table 2. Water meter selection according to "Guidelines for designing and construction of water supply and wastewater networks and service lines" [12].

\begin{tabular}{|c|c|c|c|}
\hline $\begin{array}{l}\text { Daily water } \\
\text { consumption } \\
\text { in object } \mathrm{m}^{3 *}\end{array}$ & $\begin{array}{l}\text { Number of } \\
\text { premises in } \\
\text { building }\end{array}$ & $\begin{array}{l}\text { Water meter } \\
\text { size } \\
\text { DN for typical } \\
\text { Qn parameters }\end{array}$ & $\begin{array}{l}\text { Predicted water } \\
\text { consumption for } \\
5 \text { years of water } \\
\text { meter operation }\end{array}$ \\
\hline $1.01-4.0$ & $4-15$ & $20\left(2.5 \mathrm{~m}^{3} / \mathrm{h}\right)$ & $<9125$ \\
\hline $4.0-12$ & $16-45$ & $25\left(3.5 \mathrm{~m}^{3} / \mathrm{h}\right)$ & $<21900$ \\
\hline $12.01-20.0$ & $46-75$ & $32\left(6.0^{3} / \mathrm{h}\right)$ & $<36500$ \\
\hline $20.01-45.0$ & $76-125$ & $40\left(10.0 \mathrm{~m}^{3} / \mathrm{h}\right)$ & $<91250$ \\
\hline $45.1-80$ & $\begin{array}{c}\text { Pressure } \\
\text { boosting plant. } \\
>125\end{array}$ & $50\left(15.0 \mathrm{~m}^{3} / \mathrm{h}\right)$ & $<146000$ \\
\hline $80.1-180$ & $\begin{array}{c}\text { Pressure } \\
\text { boosting plant } \\
>250\end{array}$ & $80\left(30.0 \mathrm{~m}^{3} / \mathrm{h}\right)$ & $<328500$ \\
\hline $180-300$ & $\begin{array}{c}\text { Pressure } \\
\text { boosting plant, } \\
>400\end{array}$ & $100\left(50.0 \mathrm{~m}^{3} / \mathrm{h}\right)$ & $<547500$ \\
\hline
\end{tabular}

\section{Results and discussion}

During the studied period, the percentage share of consumers in rural areas increased from year to year. The percentage share of consumers from the urban area decreased from year to year with respect to the total number of consumers in the entire water supply network. From 2011 to 2016, the number of consumers in the urban area increased by $4.87 \%$, while the number of consumers in the rural area increased by $44.37 \%$.

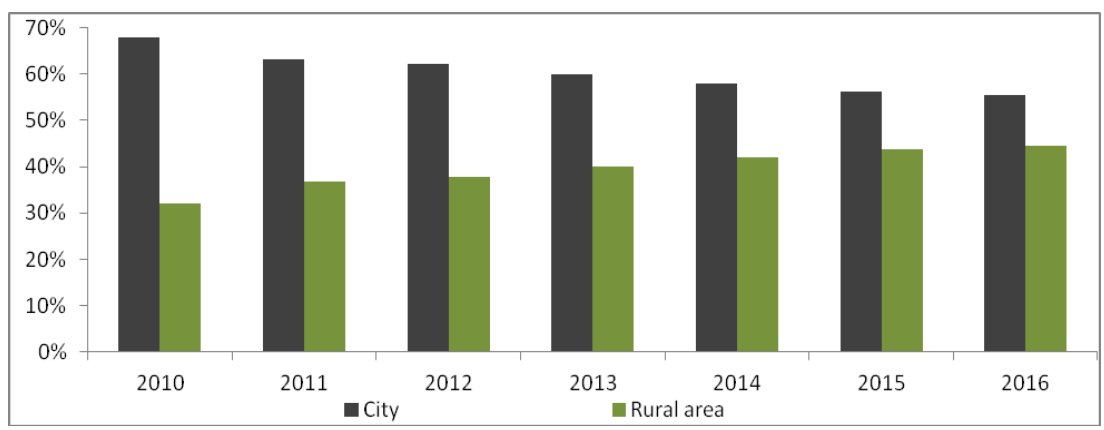

Fig. 1. Changes in the shares of consumers from urban and rural areas in the years 2010-2016. 
In the years 2010-2016, the number of water meters counted among the resources of the urban-rural water supply network increased by $29.42 \%$. The table presents how the number of water meters changed in individual years. The group of water meters with size DN 20 and DN 15 increased by the greatest amount. This is directly linked to enlargement of the water supply network's resources in the rural area, where single-family homes are dominant and there is a small number of agricultural holdings.

Table 3. Changes in the number of water meters in the water supply network.

\begin{tabular}{|c|c|c|c|c|c|c|c|c|}
\hline $\begin{array}{c}\text { Water } \\
\text { meters }\end{array}$ & 2010 & 2011 & 2012 & 2013 & 2014 & 2015 & 2016 & $\begin{array}{c}\text { Change } \\
\text { by }\end{array}$ \\
\hline DN 15 & 1888 & +79 & +79 & +85 & +25 & +93 & +167 & $27.97 \%$ \\
\hline DN 20 & 2122 & +21 & +58 & +200 & +144 & +153 & +89 & $31.34 \%$ \\
\hline DN 25 & 131 & +5 & -8 & +11 & +10 & +4 & -1 & $16.03 \%$ \\
\hline DN 32 & 37 & +2 & +5 & 0 & 0 & +2 & 0 & $24.32 \%$ \\
\hline DN 40 & 36 & +2 & +1 & 0 & +1 & +3 & +3 & $27.78 \%$ \\
\hline DN 50 & 13 & +1 & +2 & +1 & 0 & +3 & +1 & $61.54 \%$ \\
\hline DN 65 & 1 & 0 & 0 & +1 & +1 & 0 & 0 & $200.00 \%$ \\
\hline DN 80 & 8 & +1 & +3 & 0 & 0 & 0 & 0 & $50.00 \%$ \\
\hline DN 100 & 2 & 0 & 0 & 0 & 0 & 0 & 0 & $0.00 \%$ \\
\hline
\end{tabular}

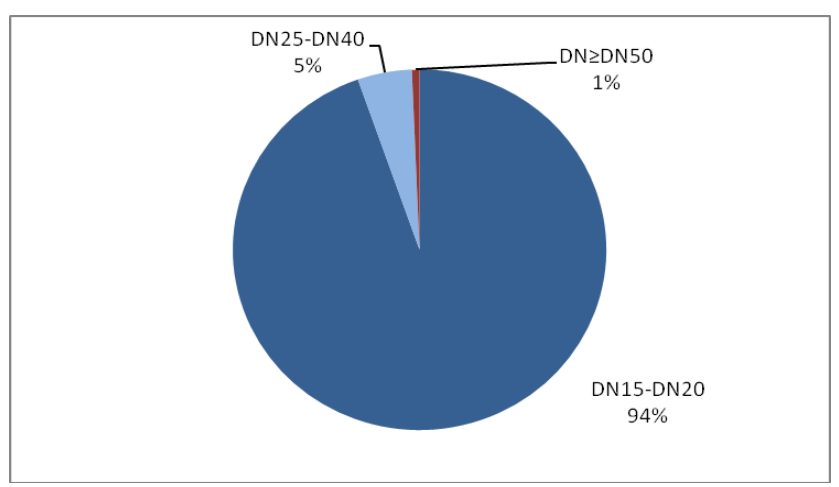

Fig. 2. Share of water meter groups in entire population.

Fig. 2. presents the percentage share of individual water meter groups in the entire water meter population of the analyzed urban-rural water supply network. As many as $94 \%$ of water meters in the entire population are DN15 water meters (44\%) and DN20 meters $(50 \%)$. Only $5 \%$ of meters are water meters within the DN25-DN32 diameter range. And water meters larger than or equal to DN50 make up only 1\% of the entire population.

The table presents how individual water meter sizes corresponded to the amount of water sold in the urban-rural water supply network. The data given in the table shows that 
DN15 and DN20 water meters are responsible for approx. 57.5\% of total water sales, and DN25-DN40 meters correspond to approx. $31.5 \%$ of total water sales. This confirms that single-family homes and small agricultural holdings are dominant in the urban-rural areas, which translates to the number of water meters with individual diameters and their share in the total amount of water sold. The second group, water meters within the DN25-40 range are typical for consumers in multi-family buildings. Less than $2 \%$ of total water sales are measured by DN50-DN65 water meters, which are typical for services or industrial consumers. Wholesale water consumers account for nearly $10 \%$ of total water sales in the analyzed urban-rural water supply network.

Table 4. Share of water meters of individual diameters in total water sales during the years 20142017.

\begin{tabular}{|c|c|c|c|c|}
\hline Diameter & 2014 & 2015 & 2016 & 2017 \\
\hline DN 15 & $18.68 \%$ & $19.46 \%$ & $40.36 \%$ & $18.90 \%$ \\
\hline DN 20 & $35.03 \%$ & $37.16 \%$ & $26.57 \%$ & $33.96 \%$ \\
\hline DN 25 & $16.12 \%$ & $16.58 \%$ & $11.45 \%$ & $15.17 \%$ \\
\hline DN 32 & $11.54 \%$ & $11.05 \%$ & $7.56 \%$ & $10.07 \%$ \\
\hline DN 40 & $7.37 \%$ & $7.26 \%$ & $5.13 \%$ & $6.63 \%$ \\
\hline DN 50 & $1.82 \%$ & $1.94 \%$ & $1.35 \%$ & $1.80 \%$ \\
\hline DN 65 & $0.00 \%$ & $0.01 \%$ & $0.00 \%$ & $0.01 \%$ \\
\hline DN 80 & $2.19 \%$ & $2.50 \%$ & $1.95 \%$ & $2.50 \%$ \\
\hline DN 100 & $7.26 \%$ & $4.06 \%$ & $5.63 \%$ & $10.96 \%$ \\
\hline
\end{tabular}

Comparing the data from figure 2 and table 4 , it can be observed that $94 \%$ of water meters account for an average of $57.5 \%$ of total water sales, $5 \%$ of water meters account for an average of $31.5 \%$ of total water sales, and $1 \%$ of water meters account for an average of $12 \%$ of total water sales in the analyzed years. Analysis of the number of devices and the amount of water metered by them shows which groups of consumers/water meters should be given more attention during selection of metering equipment.

Fig. 3. shows the period of the greatest water consumption, i.e. the period from June to September (plant vegetation period). The greatest water sales are registered in August and the lowest in February. 


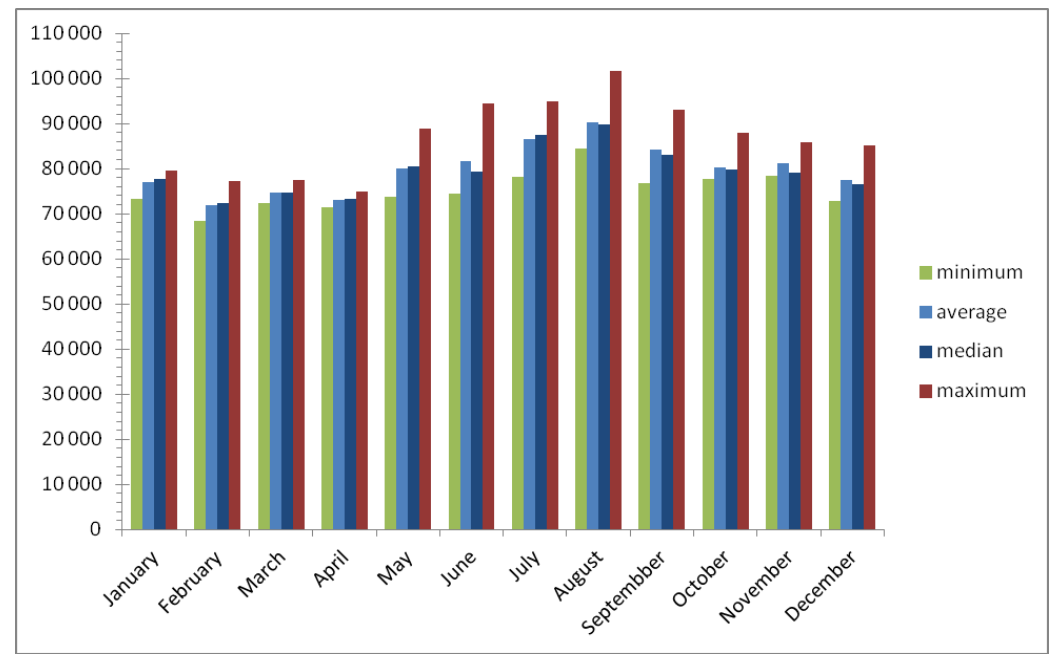

Fig. 3. Water sales in individual months during the years 2010-2016.

Based on collected data, average annual water consumption was calculated for every water meter size in the years 2014-2016. This value was converted to average daily water consumption values and then compared with guidelines for selection of water meter diameters from MPWiK in Włocławek - Variant I, PWiK of the Częstochowski District Variant II, and average daily water consumption was increased by the non-uniform distribution index, being the ratio the greatest value of monthly water sales to the average monthly value of water sales during the analyzed period, equal to 1.27. The results of water meter diameter selection indicate that a change of diameters within the given population is possible. In all cases, diameters smaller than currently installed for consumers were selected. Variant I calls for very drastic changes, i.e. accepts only DN15, DN20 and DN80 water meter diameters. Variants II and III accept 4 diameter types, i.e. DN15-20, DN25 and DN80.

In the case of reducing water meter diameter, it should be checked, in every instance, whether such a change will not have a negative impact on the pressure value at water collection points. A change of diameter in the same metrological class of the metering device will increase the capability of measuring very small flows to the consumer. This is a way to limit apparent losses arising from insufficient metering capabilities of water meters. Reduction of water meter diameter in the same metrological class simultaneously reduces the capability of measuring maximum flows. Meanwhile, reducing a water meter's size while simultaneously increasing the meter's measurement accuracy class means that the water meter can measure even smaller flows than a water meter of a lower class with the same diameter, and at the same time, it is possible to measure much higher maximum flows compared to a water meter with a lower metrological class and the same diameter.

Such selection of water meters based on average water consumption until now in individual types of water meters would cause the share of DN15 water meters to be equal to nearly $99 \%$, in Variant I. In Variant II, the share of DN15 water meters would be nearly $95 \%$, DN20 meter approx. 3\%, and DN 25 meters nearly 2\%. In Variant III, which provided for increasing average daily consumption to the value of average daily consumption in the month with maximum monthly consumption within the studied period, the results of water meter selection were identical to the results of Variant II. 
Table 5. Selection of water meter diameters according to 2 methods.

\begin{tabular}{|c|c|c|c|c|c|c|c|c|c|}
\hline \multicolumn{2}{|c|}{ average daily water } & \multicolumn{2}{c|}{ maximum average daily } & $\begin{array}{c}\text { Current } \\
\text { water } \\
\text { meter DN }\end{array}$ & $\begin{array}{c}\text { Variant } \\
\text { I }\end{array}$ & $\begin{array}{c}\text { Variant } \\
\text { II }\end{array}$ & $\begin{array}{c}\text { Variant } \\
\text { III }\end{array}$ \\
\hline 2014 & 2015 & 2016 & 2014 & 2015 & 2016 & 15 & 15 & 15 \\
\hline 0.225 & 0.223 & 0.629 & 0.286 & 0.283 & 0.799 & DN 15 & 15 & 15 \\
\hline 0.358 & 0.355 & 0.359 & 0.454 & 0.450 & 0.456 & DN 20 & 15 & 15 & 15 \\
\hline 2.809 & 2.789 & 2.836 & 3.568 & 3.542 & 3.602 & DN 25 & 15 & 20 & 20 \\
\hline 6.810 & 6.181 & 6.189 & 8.649 & 7.850 & 7.860 & DN 32 & 20 & 25 & 25 \\
\hline 4.783 & 4.349 & 4.196 & 6.074 & 5.523 & 5.329 & DN 40 & 15 & 25 & 25 \\
\hline 2.780 & 2.491 & 2.411 & 3.531 & 3.164 & 3.062 & DN 50 & 15 & 20 & 20 \\
\hline 0.003 & 0.052 & 0.043 & 0.003 & 0.066 & 0.054 & DN 65 & 15 & 15 & 15 \\
\hline 4.735 & 5.353 & 6.101 & 6.014 & 6.798 & 7.748 & DN 80 & 20 & 25 & 25 \\
\hline 94.234 & 52.234 & 105.984 & 119.677 & 66.337 & 134.599 & DN 100 & 80 & 80 & 80 \\
\hline
\end{tabular}

Table 6. Share of individual water meter sizes in the entire population as a result of new selection.

\begin{tabular}{|c|c|c|c|c|c|c|c|c|c|}
\hline \multirow{2}{*}{ DN } & \multicolumn{3}{|c|}{ Variant I } & \multicolumn{3}{c|}{ Variant II } & \multicolumn{3}{c|}{ Variant II } \\
\cline { 2 - 10 } & 2014 & 2015 & 2016 & 2014 & 2015 & 2016 & 2014 & 2015 & 2016 \\
\hline 15 & $98.83 \%$ & $98.85 \%$ & $98.91 \%$ & $94.69 \%$ & $94.72 \%$ & $94.91 \%$ & $94.69 \%$ & $94.72 \%$ & $94.91 \%$ \\
\hline 20 & $1.13 \%$ & $1.11 \%$ & $1.06 \%$ & $3.34 \%$ & $3.31 \%$ & $3.15 \%$ & $3.34 \%$ & $3.31 \%$ & $3.15 \%$ \\
\hline 25 & $0.00 \%$ & $0.00 \%$ & $0.00 \%$ & $1.93 \%$ & $1.93 \%$ & $1.90 \%$ & $1.93 \%$ & $1.93 \%$ & $1.90 \%$ \\
\hline 80 & $0.04 \%$ & $0.04 \%$ & $0.04 \%$ & $0.04 \%$ & $0.04 \%$ & $0.04 \%$ & $0.00 \%$ & $0.00 \%$ & $0.00 \%$ \\
\hline
\end{tabular}

\section{Conclusions}

This article presents the approximate scale of the problem of water meter size and the average amount of water measured by these meters. The problem of reduced water consumption concerns not only low water flow rates in pipes but also the issue of measuring water consumption by consumers. Based on the research results it can be concluded that water meters in analysis urban-rural water supply network are not optimally selected. During optimization of water meter size, it was assumed that every consumer with a water meter of the same size consumes the same amount of water. In the case of precise optimization, more detailed data would have to be obtained, and every consumer would be optimized individually. During optimization of water meter size, identical results were obtained when the guidelines of PWiK of the Częstochowski District were applied and 
when both of the guidelines cited in the article were applied, considering the average daily consumption in the month with maximum consumption. In urban-rural water supply networks, a large number of water meters of small diameters (94\%), i.e. DN15 and DN20, with a simultaneously high share of these water meter groups in total water sales (over $50 \%$ ) is typical. The type of consumers in rural areas using the water supply network has an effect on this. Consumers of medium size $(5 \%)$, i.e. multi-family residential buildings typical for urban areas, are most commonly represented by DN25-DN40 meters, and in the case of the analyzed water supply network, these consumers make up over $30 \%$ of total water sales in the water supply network. On this basis, it can be seen where the operators of the water supply network should pay special attention to the selection of the proper metering devices. Incorrect selection of some water meters in group DN15-DN20 would result in lower losses than incorrect selection of some water meters in group DN25-DN40 or larger than or equal to DN50. On the basis of the conducted research, the authors noticed the need to check how the optimization of water diameters influences the change in the size of apparent water losses in the water supply network.

The research has been carried out in the framework of project No. S/WBiIS/2/2014 and financed from the funds for science by Ministry of Science and Higher Education.

\section{References}

1. P. Dohnalik, PFOZW (2000)

2. H. Hotloś, Env. Prot. 25, 17-24 (2003)

3. M. Kwietniewski, Env. Prot. 35, 9-15 (2013)

4. E. Ociepa, W. Kędzia, Engine. Prot. Env. 18, 277-288 (2015)

5. J.R. Rak, Ł. Sypień, Journ. Civ. Engine. Env. Arch. 30, 5-18 (2013)

6. A. Lambert, T.G Brown., M. Takizawa, D. Weimer, Journ. Wat. Sup. Res. Tech. 48, 6, 227-237 (1999)

7. M. Farley, G. Wyeth, Z. Bin Md. Ghazali, A. Istandar, S. Singh, A Guide to Understanding Water Losses (2008)

8. H. Kłoss-Trębaczkiewicz, E. Osuch-Pajdzińska, Env. Prot .27, 63-67 (2005)

9. K. Pawęska, A. Bawiec, S. Włodek, E, Smaga, Journ. Civ. Engine. Env. Arch. 1, 171-179 (2013)

10. P.K. Tuz, J. Gwoździej-Mazur, Rynek Instal. 9, 75-77 (2012)

11. Urban Water Supply and Sewage Company in Włocławek, "Water meter selection procedure"

12. Water Supply and Sewage Company of the Częstochowski District, "Guidelines for designing and construction of water supply and wastewater networks and service lines" 